\title{
UNWELCOME DEDICATIONS: PUBLIC LAW AND PRIVATE RELIGION IN HELLENISTIC LAODICEA BY THE SEA*
}

The Seleucid Laodicea by the Sea has left us but one Hellenistic public decree (IGLS IV 1261). ${ }^{1}$ To the extent that scholars have paid close attention to this text it has been to support the argument that Seleucid kings ruled with a heavy hand, operating in concert with entrenched oligarchs and micro-managing through personal appointees. ${ }^{2}$ The decree was passed by the $\pi \epsilon \lambda \iota \gamma \hat{\alpha} \nu \epsilon s$, a council of elders and an institutional transplant from Macedonia; ${ }^{3}$ the proposal was moved by the $\epsilon \pi \iota \sigma \tau \alpha \dot{\tau} \eta \eta s$, perhaps another old Macedonian office, ${ }^{4}$ and the magistrates $(2-3) .{ }^{5}$ Thus, the inscription reminds us that Hellenistic cities were administered by powerful men who may have had the ear of the king. No news here. ${ }^{6}$ But the decree's focus is neither kings nor power politics. This was a local matter, involving a tangled mess of property rights, religious imperatives, fiscal policy, and legislative problem-solving, a neat piece of local history: ${ }^{7}$

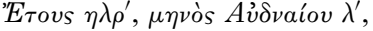

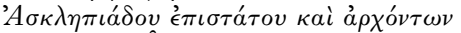

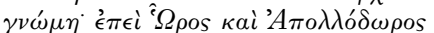

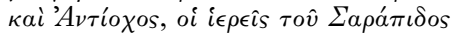

* I am grateful to Kent Rigsby, Edward Harris, and Robert Parker for their thoughtful criticism of an earlier draft of this paper.

${ }^{1}$ First published by P. Roussel, 'Décret des péliganes de Laodicée-sur-Mer', Syria 23 (1942-3), 21-32; brief notice and discussion by J. and L. Robert, Bull.épigr. (1943), 74; (1950), 208, and by G. Klaffenbach, 'Epigraphische Studien', Philologus 97 (1948), 372-9, at 376-9; letter-forms and the persistent omission of iota adscript suggest, as editors have seen, that the text was reinscribed in the imperial period. On its uniqueness: F. Millar, 'The problem of Hellenistic Syria', in A. Kuhrt and S. M. Sherwin-White (edd.), Hellenism in the East: The Interaction of Greek and Non-Greek Civilizations from Syria to Central Asia after Alexander (Berkeley, 1987), 110-33, at 117.

2 For example, J. D. Grainger, The Cities of Seleukid Syria (Oxford and New York, 1990), 153; D. Musti, CAH VII ${ }^{2} .1$ 205; O. Mørkholm, Antiochus IV of Syria (Copenhagen, 1966), 110, 115; cf. B. Dignas, Economy of the Sacred in Hellenistic and Roman Asia Minor (Oxford and New York, 2002), 80, n. 162: '[T] he priests ... appeal to the royal epistates to take care that a civic decree will not infringe their property'.

${ }^{3}$ Roussel (n. 1), 28-32. On the institution: M. B. Hatzopoulos, Macedonian Institutions under the Kings, Meletemata 22 (Athens and Paris, 1996), 323, 326, 465, 482. For a recent

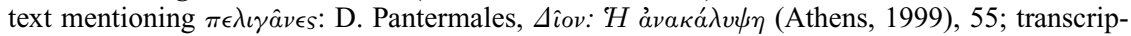
tion at M. B. Hatzopoulos, Bull.épigr. (2000), 453, p. 522.

${ }^{4}$ For example, R. Malcolm Errington, 'König und Stadt im hellenistischen Makedonien: die Rolle des Epistates', Chiron 32 (2002), 51-63; F. Papazoglou, 'Polis et Souveraineté', ZivaAnt 50 (2000) 169-76; Hatzopoulos (n. 3, 1996), 371-429, and id. (n. 3, 2000), 442, against N. G. L. Hammond, 'The roles of the epistates in Macedonian contexts', ABSA 94 (1999), 369-75; also S. Le Bohec, 'Les épistates des rois antigonides', Ktema 11 (1986) [1990], $283-8$.

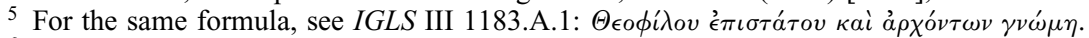

${ }^{6}$ Recently J. Ma, Antiochos III and the Cities of Western Asia Minor (Oxford and New York, 1999), $122-47$.

7 Text from L. Jalabert and R. Mouterde, IGLS IV 1261, except for the dittography in 10

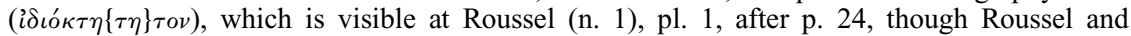
Jalabert and Mouterde include no mention in their texts; Klaffenbach (n. 1), 377, did. 


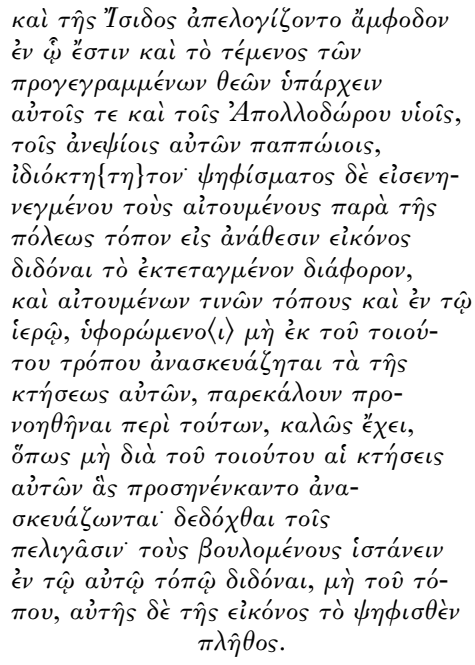

Year 138 [174 B.C.], on the thirtieth of the month of Audnaios, proposal of Asclepiades $\dot{\epsilon} \pi \iota \sigma \tau \alpha \dot{\alpha} \tau \eta s$ and the archons. Since Horus and Apollodorus and Antiochus, priests of Sarapis and Isis, declared that a block of houses, ${ }^{8}$ in which also stands the precinct of the aforesaid gods, belongs to them and to the sons of Apollodorus, their grandpaternal cousins, as private property; and since a decree has been passed that those requesting from the city a place for the dedication of a statue shall pay a fixed fee, and some are seeking places in the precinct; being anxious lest their possessions be dismantled in such a manner, they asked that consideration be given concerning these matters: it is well that their possessions, which they have exhibited, may not be dismantled in such a way: it has been resolved by the $\pi \epsilon \lambda \iota \gamma \hat{\alpha} \nu \epsilon s:$ those who wish to erect (a statue) in the same place shall give the decreed sum, not for the place, but for the statue itself.

The complex situation warrants close scrutiny. Three men, evidently brothers, and their cousins owned an $\ddot{\alpha} \mu \phi o \delta o v$, perhaps an entire quarter, ${ }^{9}$ but most likely an insula in a city block. The property included a precinct sacred to Sarapis and Isis, of whom the three men were priests. Nothing extraordinary so far. A contemporary private association of Dionysiasts in Piraeus $\left(I G \mathrm{II}^{2} 1325,1326,2948\right)$ met in a large open sanctuary that was embedded in the urban fabric, attached to the priest's house, and may have occupied as much as half of an insula. ${ }^{10}$ The

8 Roussel (n. 1), 22, was certain that the text should read $\dot{a} \pi \epsilon \lambda o \gamma i \zeta_{\text {ov }} \tau o\langle\tau \dot{o}\rangle$ á $\mu \phi o \delta o v$; Jalabert and Mouterde p. 23, concurred. Neither included the addition in the text; again, Klaffenbach (n. 1), 377, did. It does not seem strictly necessary, except perhaps in the light of $\tau \dot{o} \tau \epsilon \in \mu \epsilon \nu$ os (6).

9 D. Hennig, 'Strassen und Stadtviertel in der griechischen Polis', Chiron 30 (2000), 585615; also E. Greco, 'Nomi di strada nelle città greche', in M. Castoldi (ed.), Kovvó: Miscellanea di studi in onore di Piero Orlandini (Milan, 1999), 223-9; Arados: IGLS VII 4002, with L. Robert, 'Inscription d'Arados', in Mélanges syriens offerts à monsieur René Dussaud, BAH 30 (2 vols; Paris, 1939), 2.729-31; Damascus: SEG II 839; Scythopolis: SEG VIII 44; Egypt: H. Rink, Strassen- und Viertelnamen von Oxyrhynchus (Darmstadt, 1924), 9-16; Amastris: C. Marek, Stadt, Ära und Territorium in Pontus-Bithynia und Nord-Galatia, IstForsch 39 (Tübingen, 1993), no. 56, with pp. 93-5 (SEG XXX 1449); amphodarchs at Pergamon: OGIS II 483.35-100.

${ }_{10}$ W. Dörpfeld, 'Ein antikes Bauwerk im Piraeus', $M D A I(I) 9$ (1884), 279-87, at 286, with pls XIII-XIV; U. Köhler, 'Die Genossenschaft der Dionysiasten in Piraeus', MDAI(A) 9 (1884), 288-98. Location: W. Hoepfner, E.-L. Schwandner, et al., Haus und Stadt im klassischen Griechenland (Munich, 19942), 24-9, with fig. 19; 41-2, with fig. 14. Brief description of the complex at K.-V. von Eickstedt, Beiträge zur Topographie des antiken Piräus (Athens, 
precinct that Asclepius instructed Demon of Paeania to dedicate may have been similar. $^{11}$

The problem was this. The shrine sat on and was private property: the entire

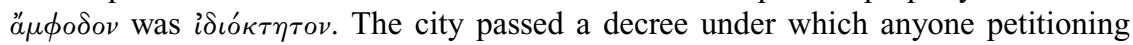
the city for a piece of land, necessarily polis-owned, on which to dedicate a statue had to pay a fee. Call it a tax for use of public property. Now, certain individuals were also requesting spots for dedication in the privately owned precinct of Sarapis and Isis. The priests and their cousins feared that this trend might result in the ruin of their private property. The narrative is elliptical and paratactic, but we may offer a plausible reconstruction of the underlying events and logic. The decreed fee did not apply to the precinct of Sarapis and Isis, which was private property, not ground that individuals would request 'from the city' ( $\pi \alpha \rho \dot{\alpha} \tau \hat{\eta} s \pi o ́ \lambda \epsilon \omega s)$. Thus, dedicators who were concerned for both piety and their purses took their statues to the private sanctuary in order to avoid having to pay. The priests experienced, or at least envisaged, an increase in the volume of dedications, exceeding the precinct's capacity. The result, actual or imagined, was damage to the priests' private property.

Theirs was not an extraordinary concern. Dedication required care lest the new injure the old, as a Parian decree shows. ${ }^{12}$ A Milesian decree banned affixing dedications to the woodwork of a new stoa in the precinct of Apollo; ${ }^{13}$ wood was expensive and nails can do irreparable damage. Aesthetics were a concern: at Athens statues might be forbidden from crowding the tyrannicides. ${ }^{14}$ A sacred law from Loryma in the Rhodian Peraea, if the text has been restored correctly, barred any rearrangement of dedications contrary to their current disposition. ${ }^{15}$ A Rhodian decree banned all requests for the right to leave dedications in certain sections of the precinct of Asclepius, a place in which the volume of dedications might easily have grown out of control. ${ }^{16}$ Installing dedications could entail substantial alteration to the physical

1991), 156-7, 201; also R. Garland, The Piraeus: From the Fifth to the First Century B.C. (Ithaca, NY, 1987), 146; B. C. Rider, Ancient Greek Houses: Their History and Development from the Neolithic Period to the Hellenistic Age (1946; repr. Chicago, 1964), 222-4.

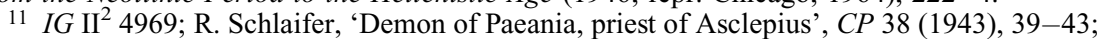
S. B. Aleshire, The Athenian Asklepieion: The People, their Dedications, and the Inventories (Amsterdam, 1989), 163-4.

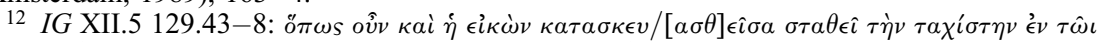

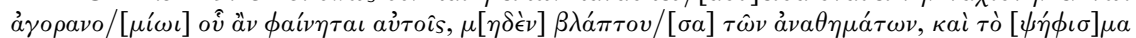

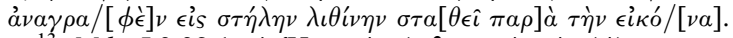

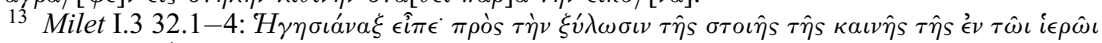

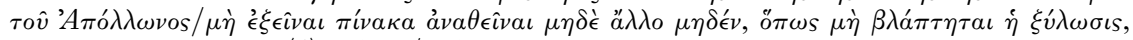

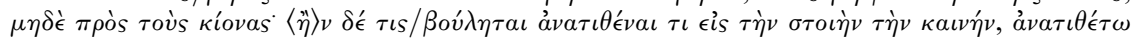

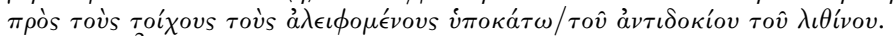

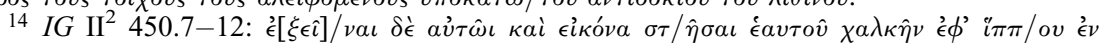

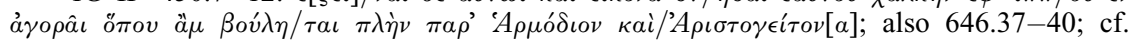

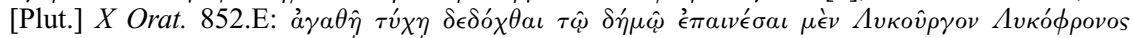

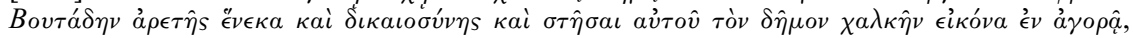

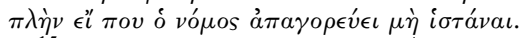

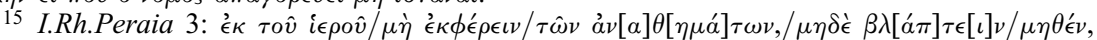

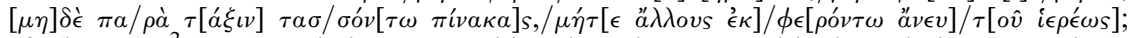
cf. also $I G \mathrm{II}^{2}$ 995. Permission to reposition the cult statue and its base during renovations: E. Varinlioğlu, 'East of Halicarnassus', in S. Isager and P. Pedersen (edd.), The Salmakis Inscription and Hellenistic Halikarnassos (Odense, 2004), 125-31, at 127-8, no. 1.7-10:

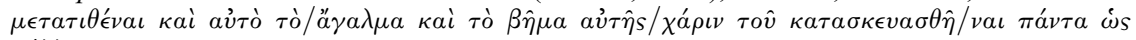
$\kappa \alpha ́ \lambda \lambda \iota \sigma \tau \alpha$.

16 G. Pugliese Carratelli, 'Supplemento epigrafico rodio', ASAtene 30-2 n.s. 14-16 (1952-4), 247-316, 1.20 at pp. 247-9; cf. Bull.épigr. (1948), 172. Some tentative emendations may be proposed. At 2-10 Pugliese-Carratelli largely followed the Roberts, printing [ $\epsilon^{\prime} \delta o \xi \epsilon \tau \hat{\alpha} \iota$ 
environment: cutting, drilling, digging, pinning, obscuring sightlines, obstructing or rerouting pedestrian passage. ${ }^{17}$ All of this was, on one view, a natural and welcome feature of piety but, on another, potentially destructive.

The worry of the priests was lest their property be dismantled ( $\alpha \nu \alpha \sigma \kappa \epsilon v a ́ \zeta \eta \tau \alpha \iota)$. The word is rather rare in inscriptions, especially before the imperial period, but at its most common and fundamental level the verb and its etymological relatives indicated the breaking up, dismantling, or destroying of places, contracts, arguments, laws, and so on. ${ }^{18}$ Use of the verb in formulaic injunctions against destroying tombs may not appear on stone till the third century A.D., ${ }^{19}$ but the fundamental denotation 'to destroy' is at least as old as Thucydides (4.116.2). ${ }^{20}$ Roussel translated lines 15-17 as 'craignant que, par ce procédé, leurs droits de propriété ne soient mis en danger', invoking instances in which the verb is used to describe the breaking of contracts and oaths (LSJ I.2). ${ }^{21}$ But in the section immediately following, in which the

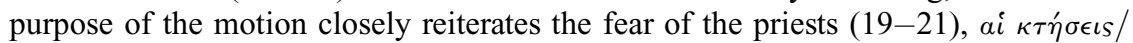
$\alpha \dot{v} \tau \hat{\omega} \nu$ must be equivalent in both syntax and meaning to $\tau \dot{\alpha} \tau \hat{\eta} s / \kappa \tau \dot{\eta} \sigma \epsilon \omega s$ a $\tau \hat{\omega} \nu$. Both clauses address the threat to the property itself, not to property rights. Where a $\nu \alpha \sigma \kappa \epsilon v \alpha \dot{\zeta} \omega$ indicated the repeal or annulment of a law, as Roussel suggested it does here, it inevitably governed a direct object or had as its subject a noun indicating as much. ${ }^{22}$ Space was limited. This was not a sprawling extra-urban shrine, but more probably a courtyard attached to a house or two. There might come a time when any new dedication meant the crowding, damage, or removal of a pre-existing token of piety. Roussel was surely right to suggest that the priests were worried about their property rights, but according to the Greek they feared damage to the property itself, not the repeal of an unstated law. This was a general verb for a general concern: lest any of their property be taken apart in any way.

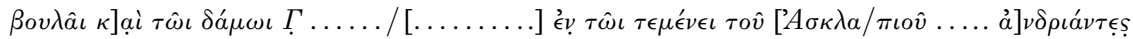

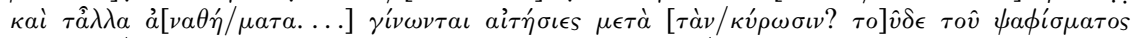

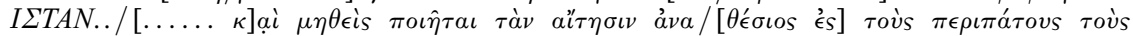

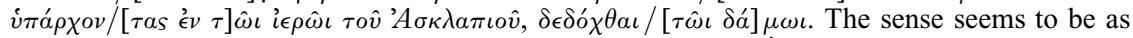
follows: it is decreed that statues and other things may not be dedicated (ö $\pi \omega s$ $\mu \grave{\eta}+$ subjunctive, as the Roberts saw) and no one may lodge a request for dedication. Thus,

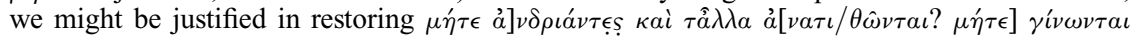

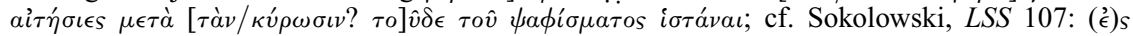
$\tau \grave{\alpha} \nu[\grave{i \epsilon} \rho \dot{\alpha} \nu / \sigma \tau o \grave{\alpha} \nu$. For another outright ban, see e.g. CID IV 85.7-13.

17 On various features of dedication: F. van Straten, 'Votives and votaries in Greek sanctuaries', in A. Schachter and J. Bingen (edd.), Le Sanctuaire grec, EntrHardt 37 (Geneva, 1990), 247-84.

18 See the very full entries in $D G E$; also LSJ; for verbal dismantling, or refutation, see $S E G$ XLVIII.1029.1. In inscriptions of the imperial period the verb sometimes indicated restoration or reconstruction: e.g. CIRB 897.1-5; cf. CIRB 1052.5-7; IG XIV 637.4-5; also (?): IosPe I ${ }^{2}$ 185.3-5; this, however, does not seem possible here, as the priests were not concerned lest their property be 'restored'.

${ }_{19}$ For example, IG V.1 822.5-7; L. Robert, Hell. XI/XII (1960), 389-90 with n. 12; also G. Petzl, 'Neue Inschriften aus Lydien (I)', EpigAnat 26 (1996), 1-29, at 13 with n. 70 (SEG XLVI 1510.14).

20 At $I G \mathrm{I}^{3} 386$. iii.151-2 (408/7 B.C.) it seems to indicate dismantling or removal of rock.

21 Robert (n. 19), 389-90, n. 12, and J. and L. Robert (n. 1, 1943), 74, p. 346, offer additional parallels but make no claim as to the validity of Roussel's suggestion; Klaffenbach (n. 1) offered no insight on this point.

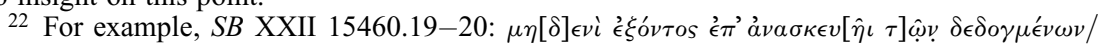

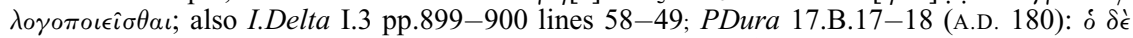

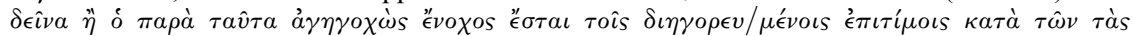

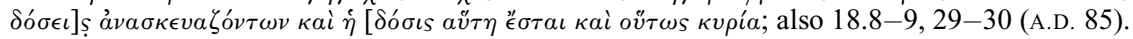


If their worry was somewhat vague, their actions were not. The three priests declared $\left(\dot{\alpha} \pi \epsilon \lambda o \gamma^{\prime} \zeta \zeta_{o \nu \tau o}\right)$ that the precinct was theirs and under threat. This was a formal presentation, perhaps before the $\pi \epsilon \lambda \iota \gamma \hat{\alpha} \nu \epsilon s, \dot{\epsilon} \pi \iota \sigma \tau \alpha \dot{\alpha} \tau \eta s$, or magistrates. The

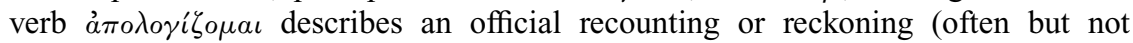
always by ambassadors, $\theta \epsilon \omega \rho o i$, and so on) before an assembly, council, or other state or civic body, ${ }^{23}$ including expense reports made by magistrates. ${ }^{24}$ This formal presentation seems to have included the submission of a list of threatened property. Jalabert and Mouterde (p. 22) followed Roussel in translating ai $\kappa \tau \dot{\eta} \sigma \epsilon \iota s / \alpha \dot{v} \tau \hat{\omega} \nu$ as

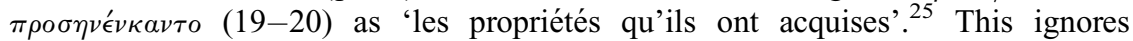
$a \dot{v} \tau \hat{\omega} \nu$-leurs not les - and makes for redundant Greek. Moreover, the active and middle of $\pi \rho \sigma \sigma \phi \epsilon^{\prime} \rho \omega$ do not indicate acquisition, ${ }^{26}$ but rather the exhibiting of abstract qualities ${ }^{27}$ the conferral of property ${ }^{28}$ the presentation or contribution of concrete objects, ${ }^{29}$ the declaration of information. ${ }^{30}$ Not acquisition but the opposite. The property at risk and in question was 'exhibited' as part of the priests' petition. ${ }^{31}$ Acquisition, possession, and ownership were not at issue. These were the givens of the case, which was about potential damage to private property. The brothers declared

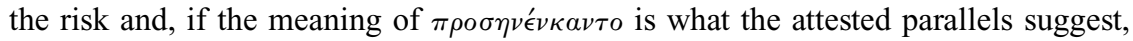
enumerated the threatened objects.

The cult, and perhaps some of the threatened objects, may have been in the family for some time. The three priests declared that the block and precinct were owned by themselves and the sons of Apollodorus, their grandpaternal cousins ( $\tau$ ois á $\nu \in \psi$ ío $\alpha \dot{v} \tau \hat{\omega} \nu \pi \alpha \pi \pi \dot{\omega} \iota \circ \iota s)$. The phrase is, so far as I know, unique in ancient Greek. Does it mean that these cousins were the priests' grandfather's (or grandmother's) brother's children? If so, might it suggest that ownership could be traced back to the three brothers' grandfather, their cousins' father? Or were the two sets of brothers simply descended from a common grandfather? ${ }^{32}$ Whatever the relationship, the phrase might indicate that the shrine had been in the family for as long as three generations. Elsewhere, the third generation was a kind of benchmark for legal or social legitimacy. A famous Ptolemaic ordinance required those who worshipped Dionysus in the $\chi \omega ́ \rho \alpha$ to sail down to Alexandria and submit a sealed report that included

${ }_{23}$ IG V.1 4.3-6; IX ${ }^{2} .1$ 12-13; Fouilles de Delphes III.3 146.11-12; III.4 31.2-4; III.4 427B.i.4-6; Syll. ${ }^{3}$ 604.3-7; SEG XII 373.2-5; 374.2-5; IC II.xii 21.9-11; Robert, Coll. Froehner 92-3; Syll. ${ }^{3}$ 590.A.27-32.

${ }^{24}$ For example, $I G$ VII 303.A.37-9 (=I.Oropos 324); VII 4131.36-7; CID II 75.i.48-9; IG $\mathrm{II}^{2}$ 956.19; IG $\mathrm{II}^{2}$ 958.14-16.

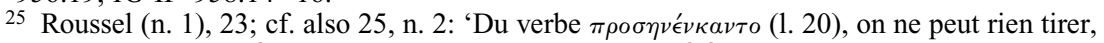
semble-t-il, sur la manière dont les biens de la famille ont été acquis.'

26 The sense 'to lay one's hands upon something', which might imply acquisition, seems

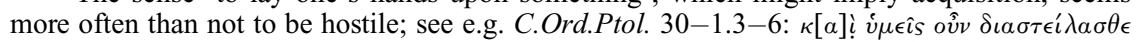

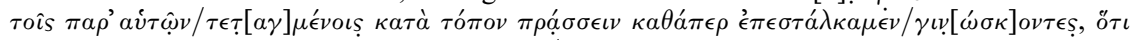

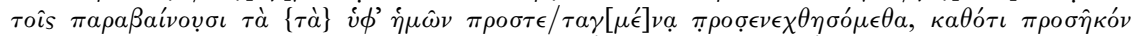
$\dot{\epsilon} \sigma \tau \iota v$; it cannot have been in the priests' interest to claim ownership through violent seizure.

27 SEG XXV 112.7-8; IG X $\mathrm{X}^{2} .1$ 4.8; I.Pergamon II 252.44-6; I.Smyrna II.1 579.52.

28 Welles, Royal Corres. 18.14-16, with lexical notes at pp. 360-1.

29 SEG XXIV 135.27-9; IG IX.2 522.20; SEG XXXIV 4369.10-12; IG II $^{2} 2291$ a.9.

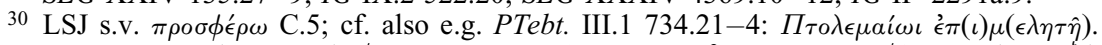

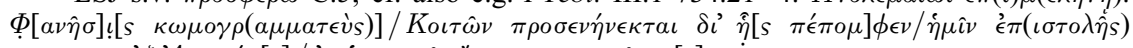

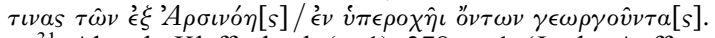

31 Already Klaffenbach (n. 1), 378, n. 1: 'In der Auffassung dieses Relativsatzes weiche ich von Roussel ab, der ihn mit "(les propriétés) qu'ils ont acquises" übersetzt (vgl. auch p. 25 not. 2), während ich verstehen möchte: "die sie angeführt, zur Sprache gebracht haben."”

32 Roussel (n. 1), 24, n. 3: 'J'en conclus que ceux-ci devaient être frères et qu'ils avaient un grand-père paternel ou maternel commun avec ces enfants.' 
record of the transmission of the $i \epsilon \rho \alpha$ back through three generations. ${ }^{33}$ In an equally well-known inscription from Delos, Apollonius, the priest of Sarapis, began his

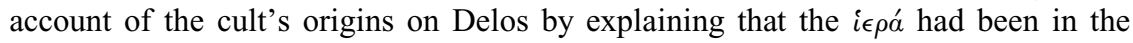
family for three generations, passed down from Apollonius' grandfather to his father and then to himself. ${ }^{34}$ Perhaps Laodicea or the king had enacted an ordinance similar to the Ptolemaic one, under which owners of certain cult sites had to legitimate their operations in some way. If so, then the priests of Sarapis and Isis must successfully have made the case, since the polis ruled in their favour. Or perhaps the brothers wanted simply to stress that their precinct was well established and worthy of respect and protection. Either way, whether this was legal stipulation or social convention, the principle was the same, and a stock fixture of Greek religious sensibility: old is good. ${ }^{35}$

The categories 'public' and 'private' have long occupied the attention of students of the ancient economy. ${ }^{36}$ Scholars have often pointed to slippage between the two. ${ }^{37}$ Here, the distinction was real, recognized, and rigorously enforced. ${ }^{38}$ The decree imposing a fee on all who wanted to dedicate statues on civic land absolutely did not apply to the privately owned shrine of Sarapis and Isis. The consecrated ground was not something between public and private. ${ }^{39}$ It was private, pure and simple. ${ }^{40}$ Of this, no one was in doubt. Nevertheless, laws affecting public property can have unintended consequences for private landowners. Such was the case here, and the owners of Sarapis and Isis' precinct requested a special amendment protecting their interests. The polis agreed, but did not compromise or undermine the general standing of private property, this or any other. The new ruling was not a blanket reform but

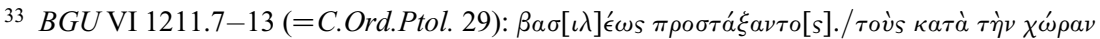

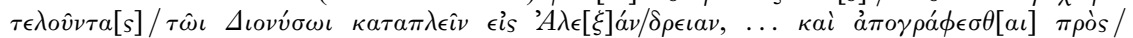

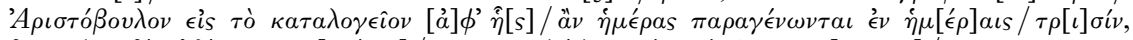

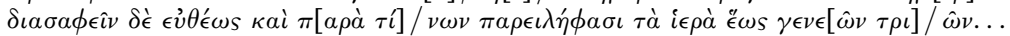

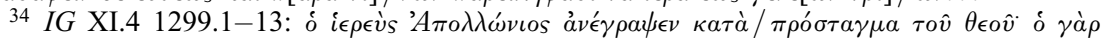

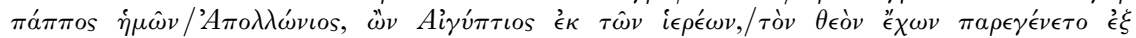

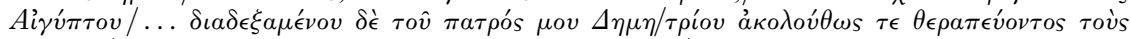

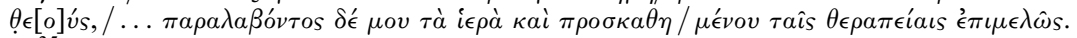

35 Eligibility to hold the priestesshood of Artemis Pergaea at Halicarnassus depended on descent from three generations of citizens on both sides of the family: Syll. ${ }^{3} 1015.3-7$. The social and religious importance of the third and subsequent generations is almost proverbial; Nestor ruled over three generations: Hom. Il. 1.250-2; cf. Il. 20.307-8; Tyrt. 12.29-30 West; Sol. 13.29-32 West, on which Arist. Eth. Nic. 1100a.

36 One recent and excellent example: R. Descat, 'Public et privé dans l'économie de la cité grecque', Ktema 23 (1998), 229-41.

37 The alleged lack of a formal distinction between the two was fundamental to Finley's conception of the ancient economy: A. Bresson, 'Prosodoi publics, prosodoi privés: le paradoxe de l'économie civique', Ktema 23 (1998), 243-62 (=id., La Cité marchande [Bordeaux, 2000], 243-61).

38 Not just here; cf. e.g. G. Thür and H. Taeuber, Prozessrechtliche Inschriften der griechischen Poleis: Arkadien (IPArk), SitzWien 607 (Vienna, 1994), 3.37-40 (=IG V.2 6): $\epsilon i \delta$

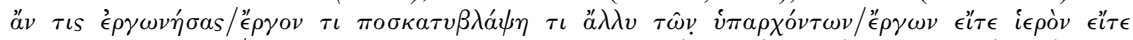

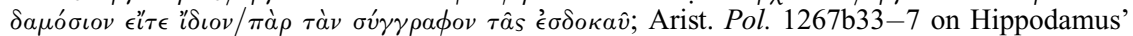

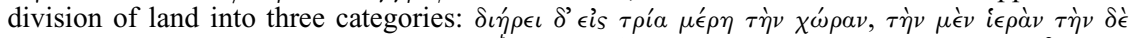

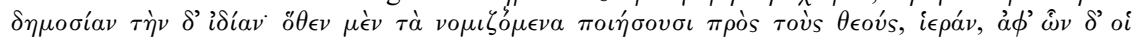

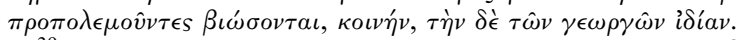

39 On this formulation in general, see A. Jacquemin, "Hiéron", un passage entre "idion" et "dèmosion"”, Ktema 23 (1998), 221-8.

40 Adducing IGLS IV 1261 as a parallel, apparently, for the legal authority of the priest of Zeus Baetocaece (IGLS VII 4028), Dignas (n. 2), 80, n. 162, notes that 'it is remarkable that the priests privately own the territory on which the sanctuary is situated'. Legal realities at Baetocaece, which was not a polis, strike me as fundamentally dissimilar. 
rather an exception, and it was spelled out carefully. The amendment applied only to

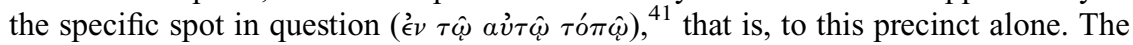
fee that the polis would extract from dedicants was tied not to the spot of dedication

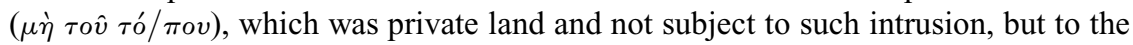
particular statue in question ( $\alpha \hat{v} \tau \hat{\eta} s \delta \dot{\epsilon} \tau \hat{\eta} s \in \hat{i}$ Kóvos), to which the city was evidently free to attach any form of taxation it saw fit. ${ }^{42}$ The logic of the episode depends on a clean legal distinction between public and private. This decree did not intrude on the rights of property-holders but protected them against unintended negative consequences of civic legislation.

There is a fiscal and economic side to this story as well. Civic finance in the Hellenistic world has not always attracted great scholarly attention, although we may hope that this trend is changing. ${ }^{43}$ Laodicea generated revenue through imposing the fee for dedicating statues on public ground. Returns may have been modest, but every bit helped and small change compounded. ${ }^{44}$ Taxation in Greek cities is a murky subject, ${ }^{45}$ yet it lies at the heart of this story. Conflict at Laodicea emerged from a civic initiative to impose a targeted tax on a certain use of public land. The consequent rush to erect statues on private soil would have entailed the loss of revenue that would otherwise have fallen to city coffers. The priests became aware of the problem before the polis; they brought the complaint. This is as we would expect. The city would have had no easy way to determine the volume of dedications before the fee was imposed. Though the city might have been able to derive the number of dedications from the total income from fees, after they were imposed, few scholars, I think, would contend that any such monitoring was the norm. Moreover, it cannot have been the case that all would-be dedicants sought a plot in

41 Klaffenbach (n. 1), 378: 'an demselben, d. h. dem vorhergenannten Orte'; see also J. and L. Robert (n. 1, 1943), 74; (n. 1, 1950), 208; for this use of the phrase, see TAM II 1201.b.8-9; III 4.26; V 1027.A.7-8; IG XIV 760.18; IG XII.3 466.15.

42 It does seem extraordinary that the city should have imposed a fee for dedication of a statue on private property. This, however, was the fact of the ruling (21-5: 'those who wish to erect [a statue] in the same place shall give the decreed sum, not for the place, but for the statue itself'), and this particular fee did not apply to all dedications on private land, but only to those made in the precinct in question.

43 For a recent survey, see L. Migeotte, 'La cité grecque, les citoyens et les finances publiques', LEC 70 (2002), 13-26; also id., 'Les finances publiques des cités grecques: bilan et perspectives de recherche', Topoi 5 (1995), 7-32. It is a shame that Rostovtzeff, $S E H H W$ (Oxford, 1941), and A. H. M. Jones, The Greek City from Alexander to Justinian (Oxford, 1940), appeared before Roussel published the inscription; subsequent editions did not include the text.

44 At Athens the Lycurgan $\delta \epsilon \rho \mu \alpha \tau \iota \kappa o ́ v$, a fund fed by sales of hides from sacrificed animals, generated annual revenues approaching one talent: $I G \mathrm{II}^{2} 1496.68-92$, esp. 90-2, 123-5, 136, 151; on the fund and sacrifices, see J. D. Mikalson, Religion in Hellenistic Athens (Berkeley, 1998), 36-9; M. Faraguna, Atene nell'età di Alessandro: Problemi politici, economici, finanziari, MemLinc ser. 9.2 (Rome, 1992), 373-7.

45 See L. Migeotte, 'Taxation Directe en Grèce ancienne', in G. Thür and F. Javier Fernández Nieto (edd.), Symposion 1999 (Cologne, Weimar, and Vienna, 2003), 297-313; idem, 'Quelques aspects légaux et juridiques de l'affermage des taxes en Grèce ancienne', in E. Cantarella and G. Thür (edd.), Symposion 1997 (Cologne, Weimar, and Vienna, 2001), 165-74; É. Roland and L. Migeotte, 'Colophon et les abus des fermiers des taxes', $B C H$ 122 (1998), 143-57. There remains significant disagreement over basic facts of the new Athenian grain-tax law: E. M. Harris, 'Notes on the new grain-tax law', ZPE 128 (1999), 269-72; M. Faraguna, 'Intorno alla nuova legge ateniese sulla tassazione del grano', Dike 2 (1999), 63-97; J. Engels, 'Das athenische Getreidesteuer-Gesetz des Agyrrhios', ZPE 134 (2001), 97-124; R. Osborne, 'Tax farming', CR 50 (2000), 172-3; A. Moreno, 'Athenian bread-baskets: the grain-tax law of 374/3 B.C. re-interpreted', ZPE 145 (2003), 97-106. 
the private shrine. Rather, the surge in dedications will have come from those who wished to make offerings to Sarapis and Isis. Thus, the reduction in civic income may have been quite small. The desire to recover the lost revenue stream may have provided added incentive to the $\pi \epsilon \lambda \iota \gamma \hat{\alpha} \nu \epsilon s$ to enact this amendment, but their primary objective appears to have been safeguarding the private precinct, not the public revenues.

The resolution of the problem had economic dimensions as well. The priests complained that their sanctuary was in danger. The $\pi \epsilon \lambda \iota \gamma \hat{\alpha} \nu \epsilon s$ appear to have seen that overcrowding was not the problem itself but a symptom, an unwelcome result of a theoretically unrelated fiscal initiative. They did not issue a decree forbidding people to dismantle the sanctuary, which would have answered the priests' complaint directly. Nor did they rule that fees always be attached to the statues rather than the ground, which would have amounted to the nullification and replacement of the previous law, but would also have risked adversely affecting other privately owned shrines that were not suffering from overcrowding. Rather, they attacked the problem's underlying cause. By imposing fees for dedicating statues on public land the city had, inadvertently I assume, created an economic condition that may have encouraged expressions of piety on private land and had the opposite effect on public property. The solution was not to tread on the rights of propertyowners, nor to forbid the pious to frequent the shrine, nor to remove the fees, but to void the economic incentive. By attaching the same fee as previously decreed ( $\tau \dot{o} \psi \eta \phi \iota \sigma \theta \dot{\epsilon} \nu / \pi \lambda \hat{\eta} \theta 0 s$ ) to the statue rather than to the land, in this particular sanctuary at least, the polis removed the financial incentive to dedicate in the one place rather than the other. Dedicating a statue would cost the same on public and private land alike. The pious would dedicate statues in accordance with religious, not economic, preference. Whether this amendment set a precedent and invited claims from other owners of sanctuaries we do not know. Nevertheless, this seems to have been an elegant and efficient piece of legislation. It shows a light touch, not a heavy hand, respecting private property, maintaining and even enhancing the city's revenue stream, and correcting a trend that threatened not only to damage a private cult site but also to deter pious displays on public land, a risk no godfearing state could afford.

We must not lose sight of the religious dimension of this episode. The polis often took an interest in piety on private property. According to the Ath.Pol. (60.2), the punishment for uprooting one of the sacred olives in Attica had once been death (cf. Lys. 7.3, 32). Many had roots in private soil (cf. Lys. 7.4-11), but Athenians may have thought them propagated from the tree that Athena had long before given to the city, ${ }^{46}$ with the result that the sacred olives belonged to the polis. But if all these trees belonged to Athens, the Herms desecrated on the eve of the Sicilian expedition were another story (And. 1.34-70). Andocides (1.62) claimed that the only Herm to escape mutilation was one dedicated by the tribe of Aegeis near the shrine of Phorbas, ${ }^{47}$ and while this may have resided on public ground, Herms that guarded the entrances to private homes probably did not. Here, sacrilege on and against private property was a state concern to rival all others. In another famous episode the Athenian statesman Lycurgus proposed to grant the right to own land ( $\epsilon \ddot{A} \gamma \kappa \tau \eta \sigma \iota s)$

46 S. Isager and J. E. Skydsgaard, Ancient Greek Agriculture: An Introduction (London and New York, 1995), 203-4.

47 Cratippus FGrHist 64 F 3 seems to have suggested that only the 'Herms around the agora'

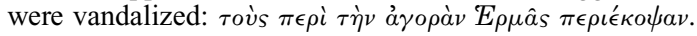


to a group of Cypriot merchants so that they might erect a shrine to their Aphrodite. ${ }^{48}$ This may well have been an attempt 'to make Athens attractive to revenue-producing metics'. ${ }^{49}$ But Lycurgus' piety was famous and it is an undeniable feature of polytheism that the well-being of the gods, whether they were installed on public or private ground, could affect the state. His motivation for keeping the merchants and their patron deity happy could easily have been religious.

Athens was not alone. PEnteux. 13 reports a property dispute in a house in which a recently deceased soldier and his wife Asia were billeted. The dispute centred on a half-finished wall that lay between the two sections of the home. Asia, however, prefaced her petition to the king by noting that her husband had erected a shrine to the Syrian Goddess and Aphrodite Berenice in his half. ${ }^{50}$ Whether the shrine had anything to do with the complaint at hand the petitioner did not say. But by introducing the petition in this way Asia sent the message that more was at stake than a simple matter of private property: it was in no one's interest, least of all the Ptolemaic house, to risk insult to the Syrian Goddess and especially Aphrodite Berenice. ${ }^{51}$ In another petition from Ptolemaic Egypt an Isionomus called Epoeris writes:

An Iseum belongs to me in the aforementioned village, which happens to be in poor shape and on account of this I am unable to dwell in it, fearing lest it cave in. Therefore, I ask you, king, that you command Diophanes the $\sigma \tau \rho a \tau \eta \gamma$ 'ó to write to whoever it is appropriate (to write to) that - if what I write is true - the demolition be granted to me, on condition that when I rebuild I restore it to the same state and that sacrifices be conducted on behalf of you and your sister and children.

(PEnteux. 6.2-6) ${ }^{52}$

Diophanes forwarded the petition to the appropriate official, instructing him, 'Taking the $\dot{\epsilon} \pi \iota \tau \alpha \dot{\alpha} \tau \eta s$ there and the village scribe, investigate and, if what she writes is true, allow demolition; but have a care that it be rebuilt again no worse than the previous

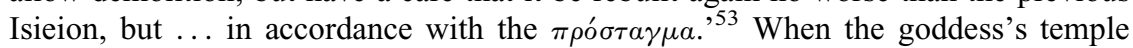
warden wanted to demolish and rebuild an existing shrine, even though it did not

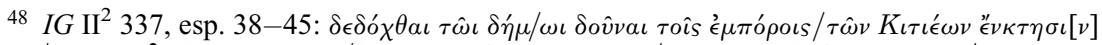

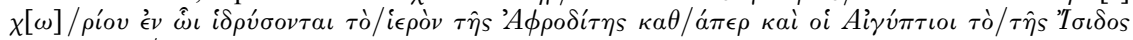
$i \in \rho o ̀ \nu ~ i \delta \rho v \nu \tau / \alpha \iota$.

49 R. Parker, Athenian Religion: A History (Oxford and New York, 1996), 243; also C. J. Schwenk, Athens in the Age of Alexander: The Dated Laws and Decrees of 'the Lykourgan Era' 338-322 B.C. (Chicago, 1985), 145-6.

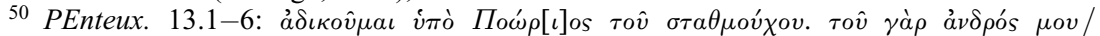

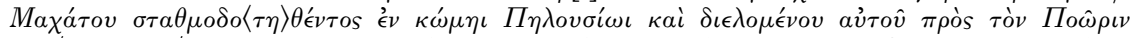

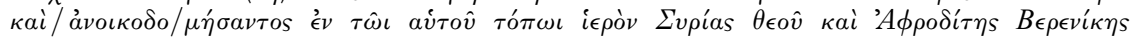

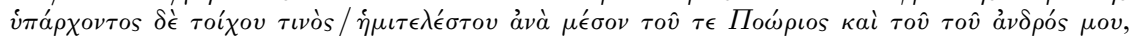

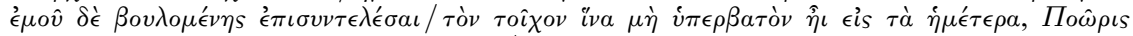

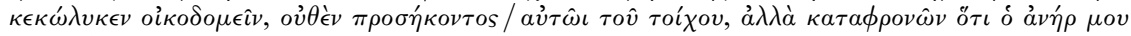
$\tau \epsilon \tau \epsilon \lambda \epsilon \dot{v} \tau \eta \kappa \epsilon$.

51 For other privately owned shrines, see PPetr. ${ }^{2}$ I 1.41-3; also PEnteux. 80; PSI V 539, esp. line 5 (with BL I 402); Apollonius' motives at PCair.Zen. II 59168.1-6 are not expressed:

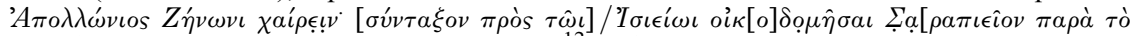

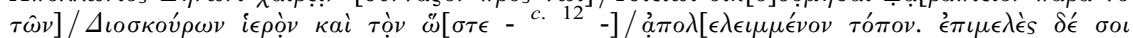

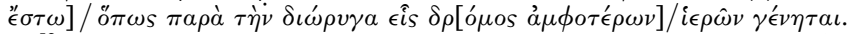

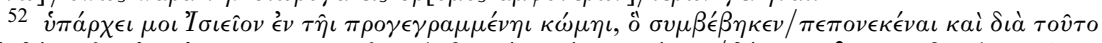

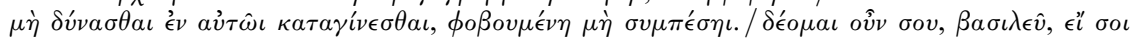

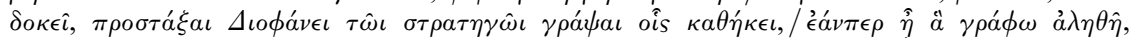

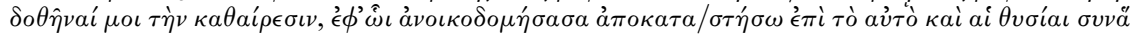

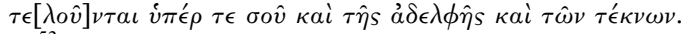

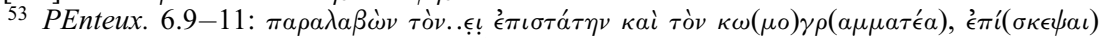

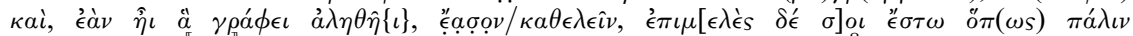

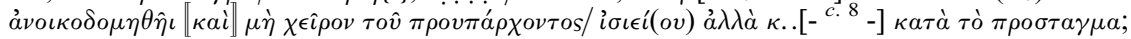


sit on royal ground, it was a state concern. There may even have been a royal ordinance $\left(\pi \rho \sigma_{\sigma \tau \alpha \gamma \mu \alpha)}\right.$ on the matter. ${ }^{54}$ Private cult was often a public concern. ${ }^{55}$ In a famous episode, the god Sarapis commanded one Zoilus to construct a Sarapeum. When he did not comply Zoilus was stricken with illness. By the time he wrote to Apollonius, Ptolemy's chief finance minister, it was to request that he, not Zoilus, follow the god's orders in order to safeguard his own, not Zoilus', reputation and bodily health. This was a private vision that may have become the burden of one of the highest-ranking officers of one of the most powerful empires in the Mediterranean. ${ }^{56}$ Divine wrath was potentially transferable, and private missteps had a way of becoming very public very quickly. Thus, we must, I suggest, add religious reasons to Laodicea's motivation to fix this problem in such an equitable fashion. The fact that Sarapis and Isis were installed on private property did not diminish their capacity to visit the city with reward or ruin. This was not polis religion, but it was a polis concern. If the legal distinction between public and private was in this case clear, piety and the gods knew no such boundaries.

Piety seems to lie at the heart of what may be the most pressing question posed by the text: if the priests owned the sanctuary, why did they resort to such extreme measures to avoid excessive dedication? What prevented them from simply turning aside would-be dedicants? As owners of the property they might have done so with ease and justification. As priests of the gods, however, they may have felt more constrained. It was common enough for sacred laws to bar the ritually impure from trespassing on holy ground. The problem here, however, was not the clientele's purity but its size. Limiting access to private cult was one thing, and a normal part of Greek religious life. But this cult appears to have been open to the public and we have to imagine that tensions might run high if use of an otherwise accessible cult site were to be closed to some pious dedicants and not to others, for no reason other than limited space. Restricting dedication in certain sections of a precinct was an option at spacious sites but may have been impractical in the urban sanctuary of Sarapis and Isis. The priests were not limited, I suggest, by any law requiring them to accept all comers. Instead, their quandary was a feature of their piety and conscience. No priest wants to turn someone away because the god has run out of room. If the ritual is right no dedication is unwelcome.

Duke University

JOSHUA D. SOSIN joshua.sosin@duke.edu

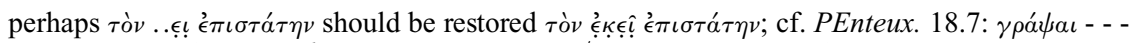

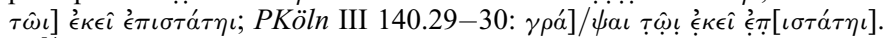

54 Epoeris does not say that she was commanded by the god to rebuild the shrine, so that it seems unlikely that the $\pi \rho \sigma^{\sigma} \tau \alpha \gamma \mu \alpha$ to which the $\sigma \tau \rho \alpha \tau \eta \gamma$ ós referred was divine; it may well have been royal, though Lenger, C.Ord.Ptol., does not cite the passage.

55 Villagers on whom soldiers were billeted were aware of the Ptolemaic policy of piety and strove to manipulate it to their own advantage: e.g. PPetr. II 12.r.10-17.

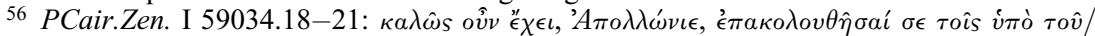

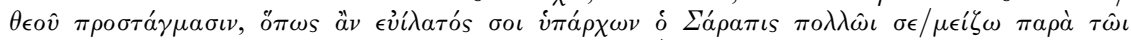

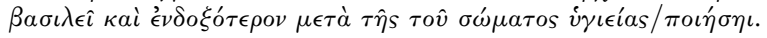

